\title{
WILLIAM HARVEY AND THE FOUNDATION OF MODERN HAEMODYNAMICS BY ALBRECHT VON HALLER*
}

\author{
by
}

\section{HEINRICH BUESS}

IT is A great honour and a pleasure to have an opportunity of presenting some aspects of the relationships between William Harvey and our country. More than a quartercentury has passed since my good friend Professor Walter Pagel in London drew the attention of medical historians to 'some neglected aspects' of the work of Harvey. Harvey's complete life's work has recently been the subject of some excellent monographs by Kenneth D. Keele, Geoffrey Keynes and Walter Pagel. I have tried to single out for treatment some pathophysiological and clinical aspects of Harvey's work, and to establish links, based on the firm evidence of earlier physiological research, between London, Basle and Berne.

First, I should like to show you three chronological tables which indicate the most important landmarks in our knowledge of the circulation. Some doctors from the School of Hippocrates had a quite considerable knowledge of the circulation. The

Historical Survey of the Discovery of the Circulation of the Blood

Time

ANTIQUTTY: from prehistoric times

Ca. 500 B.c.

Ca. 400 B.c.

Ca. 330 B.c.
Heart: Relationship to the Lungs

Vessels (arteries and veins)

Hunters and sacrificing priests observed the contractions of the heart and the pulsation in the arteries.

AlCMaron of Crotona, a pupil of Pythagoras, was probably the first to draw the ill-fated distinction between vessels filled with and vessels empty of blood.

\begin{abstract}
HIPPOCRATEs (460-377) and his pupils assumed that the blood ebbed and flowed.

Anatomy of the 2 chambers,

heart:

Function: 2 auricles closure of the semilunar valve was observed

Left ventricle: the seat of warmth, containing pneuma.
\end{abstract}

Aristorus (384-322): The heart is the central organ of the body and the seat of the soul.

Systole and diastole were attributed to the alternate expansion and contraction of the blood heated and cooled in the heart.

* Paper read at the meeting of the Harveian Society in Basle University (26 June 1969). Invitation by Sandoz Ltd. For the translation I am obliged to Mr. J. E. Smith, Basle. 


\section{Heinrich Buess}

views of the great philosopher and biologist, Aristotle, on the movement of the blood are of a more speculative nature; nevertheless, reconstruction of the anatomy of the vascular system as he knew it likewise reveals a high standard of knowledge.

The data summarized in the second table are far better known, thanks to the fine film by the Royal College of Physicians dating from 1957. It was only necessary for us to add the interesting but isolated reference to Ibn Nafis from the thirteenth century. The third table takes us to the discovery of the capillaries, the existence of which had already been postulated by Harvey.

Historical Survey of the Discovery of the Circulation of the BloOd

Time

Ca. 300 B.c.

Ca. 280 B.c.

Ca. 180 A.D.

Mimdle Ages:

Ca. 1250

The MOdern ERA 1543

1546

1553
Heart: Relationship to the Lungs

Vessels (arteries and veins)

Herophilos in Alexandria: distinguished between arteries and veins from their anatomical structure. Arteries conduct air and pneuma.

Erasistratos (Alexandria) assumes the presence of 'synanastomoses' between arteries and veins. The arteries convey the vital pneuma, the veins conduct blood to the periphery and to the right ventricle.

Galen of Pergamum (129-199)

1. Heart and arteries possess pulsatory force and mainly conduct pneuma.

3. Venous blood and pneuma are mixed in the left ventricle via anastomoses.

4. Close connection between the activity of the heart and respiration, excretion of spent substances (fuligines) by the lungs.

The Arabian physician IBN AN-NAFIS (1210-1290) was the first to recognise the lesser circulation. In the lungs the blood is 'mixed with air' and 'the finest part of it clarified'.

ANDREAS Vesaltus (1514-1564) writes in Fabrica that there is no communication between the right and left ventricle. However, he placed more trust in the authority of Galen than in his own observations.

2. The passage of blood in the veins from the liver to the periphery and to the right ventricle.

Giambattista Canano (1515-1579)

demonstrated the venous valves to Vesalius. These valves were also

known to Sylvius, a Parisian scholar.

Miguel Serveto (1511-1553): 'Passage

of the blood not .... through the

septum of the heart ... it is ....

driven a long distance through the

lungs.' (Restitutio Christianismi) 


\section{W. Harvey and the Foundation of Modern Haemodynamics by A. von Haller}

Historical Survey of the Discovery of the Circulation of the Blood

III

$\begin{array}{ll}\text { Time } & \text { Heart: Relationship to the Lungs } \\ 1559 & \text { REALDO CoLOMBO (1516-1559): 'The } \\ \text { blood is conveyed by the artery-like } \\ \text { vein to the lung; there it is diluted } \\ \text { and together with air is returned to } \\ \text { the left ventricle.' (De re anatomica) }\end{array}$

1603

H. FABRICTUS AB AQUAPENDENTE (CA. 1537-1619) published excellent drawings of venous valves, but interpreted their function wrongly

De venarum ostiolis.

1628

WILLIAM HARVEY (1578-1657) adduced experimental and mathematical evidence establishing the existence of the greater and lesser circulation (Exercitatio anatomica de motu cordis et sanguinis).

1640

JAN DE WALE (1604-1649) furnished convincing experimental proof in Leyden of the passage of the blood from the arteries into the veins (loose ligature method).

1661

Marcello Malpighi (1628-1694) observed the capillaries in the frog's lung, thereby providing the missing link in Harvey's chain of reasoning.

This is also the point of departure for our excursion through the next hundred years. Of great importance at this period were the doctrines of Kepler, Galileo and Newton which were to lead to an increasingly mechanical theory of life. Although many elements from the monumental concepts of Aristotle were retained, as Pagel and $\mathrm{W}$. von Brunn in particular have demonstrated, the investigation of the physical laws came to be based more and more on applied mathematics. This was the case for hydrostatics and subsequently for hydrodynamics.

Before we proceed, allow me to point out that among other sources I have had recourse to the preliminary papers of a Basle mathematician, the late Otto Spiess (1878-1966) and of our Emeritus Professor of Physiology, Fritz Verzár (1941) as well as the doctoral theses of two of my pupils: Dr. Fritz Huber paid tribute to the great Basle mathematician and physicist, Daniel Bernoulli (1700-1782), as a physiologist and statistician (1959); Dr. Peter Wobmann received the Henry Sigerist Prize for his thesis (1967) which is a succinct summary of the theme: haemodynamics in the work of Albrecht von Haller (1708-1777).

After this brief glance at the bibliography, back to our subject. I should like, as far as possible, to refrain from burdening you with historical dates. However, it is important to hold fast to the year 1738, this being the point when the science of hydrodynamics, which looms so large in the physiology of the circulation, was founded by the Basle physician and physicist, Daniel Bernoulli (1700-1782). A few years previously he had returned from the cold and damp of St. Petersburg to his native city where, it should be placed on record, his genius went unrecognized, as a few lines from a letter to his young friend Leonhard Euler (1707-1788) show. On 25 December 1743, Bernoulli wrote: 


\section{Heinrich Buess}

I was pleased to hear that you are planning a study of the pulsation of the arteries: I have been studying this subject for a long time and have discovered many new facts. Furthermore, many questions cannot be resolved simply because the correct measured values have not been adequately determined. Such values could be readily obtained by experiment and observation, especially those relating to the lumen of the vessels and the angles between the bifurcations [of the arteries], as well as the thickness of the vessel walls, the extension of the fibres and the force of contraction, the various resistances encountered by the fluids as they flow through the channels etc. (quoted by F. Huber).

Why was Bernoulli unable to carry out these investigations in the living animal? Short and to the point we have the answer in his own words: 'I flatter myself that my ideas were useful; but in Basle one is as good as buried and one cannot find any subsidies' (Huber). He took comfort in the fact that a great deal had been dealt with by Stephen Hales (1677-1761) in his Haemostaticks (1733). He strongly recommended Euler to read this book if he had not already done so.

The above quotation from his letter clearly shows that in his studies on the pulse, Bernoulli based his ideas on Harvey. In the third chapter of his famous book De motu cordis et saunguinis, Harvey, physician-in-ordinary to King Charles I, wrote his now classical passages: 'At the time when the heart is becoming tensed and contracting, and the chest is being struck, and in short systole is occurring, the arteries are being dilated and producing a pulsation and are in their diastole . . . There then follow his experimental proofs (sectioning, puncture), whereupon Harvey draws his conclusions: 'From these facts it appears, contrary to common beliefs, that arterial diastole is synchronous with cardiac systole, and that the arteries fill up and increase in volume because blood is forcibly driven into them by the contraction of the heart's ventricles...' (from the translation by Professor Kenneth Franklin).

Let us now glance briefly at the English investigator, Stephen Hales. He was a parson in the small town of Teddington in Middlesex. However, he owes his fame not to theological but to biophysical achievements. His name is immortalized in the history of animal physiology for his measurement of the blood pressure. 'In various animals, especially horses which were destined to be slaughtered, and in dogs, he introduced glass tubes into the femoral artery and observed the rise of blood in the tube' (Buess, 1947). His values were inaccurate since they were based on the laws of hydrostatics, but in view of his research methods Hales must be described as one of the most talented lay investigators.

More accurate values could not be determined until investigations proceeded from the laws of moving liquids. From his fundamental studies already mentioned it was but a short step for the physician, Daniel Bernoulli, to transfer his theoretical considerations and experiments to the movement of the blood in the animal organism. He took as a basis his investigations on the anatomy of the heart. As Spiess and Verzár have so fascinatingly demonstrated, Bernoulli, setting out from the physical concept of mechanical work, was the first to arrive at a reasonably accurate calculation of the work done by the heart. He took his value for the stroke-volume from Harvey's book; Daniel Passavant (1722-1799), a pupil of Bernoulli's, obtained the value for the blood pressure from Hales's book. Let us hear Bernoulli's reasoning in his own words from a report which he submitted to the Académie des Sciences in Paris in 1753 (quoted from F. Huber): 


\section{W. Harvey and the Foundation of Modern Haemodynamics by A. von Haller}

The work done by the heart (unlike that performed by other internal organs of the human body) can be calculated with reasonable accuracy, for we know that the heart beats approximately 115,200 times in the course of the day and that during systole it expels two ounces of blood. Furthermore, the observations and experiments of Mr. Hales appear to show that the blood is expelled from the heart with such velocity that it may attain a height of approximately eight feet. This holds for the left ventricle. The right ventricle performs roughly one-fourth the work of the left. It may therefore be assumed that the daily work done by the heart is equivalent to that required to raise a weight of 144,000 pounds to a height of one foot.

It should be noted that Bernoulli adopted the figures for the volume of circulating blood and heart rate as they stood from Harvey. By introducing the new physical concept of work, i.e. the product: amount of blood $\mathrm{x}$ head of pressure, he arrived at a modern value. Huber closes his chapter with the following sentence: 'Thus today we may state that the 200 years old calculation of the work of the heart by Daniel Bernoulli accords with present-day knowledge.'

It would be wrong to assume that only English and Basle investigators had a part in these fundamental studies. Historical justice demands that we mention the names of the Italian G. B. Borelli (1608-1679), the French savant François Boissier de Sauvages (1707-1777) and the Dutch physician Hermann Boerhaave (1668-1738). They all applied the laws of physics founded by Galileo to the study of the circulation of the blood. This ushered in the developments which were to lay the foundations of a new branch of physiology, haemodynamics. The last task in reaching this goal consisted in synthesising all existing findings and confirming and adding to them in further experiments. The final step was to preserve these results in a suitable literary form for posterity. The man - who was probably the only one who could have accomplished this gigantic work-was Albrecht von Haller, the greatest man of medicine of the eighteenth century.

Born in Berne in 1708 of an influential family, he showed early promise of great ability and after studying medicine at Tübingen and Leiden he graduated as a Doctor of Medicine at the age of nineteen. It is quite delightful to read in his diary his impressions of London where he met many famous natural philosophers. The treasures in the museums widened his horizons in a manner which could scarcely have been anticipated. On 19 August 1727, he visited the President of the Royal Society, Sir Hans Sloane (1660-1753), at Great Russell Street near Bloomsbury Square, in the company of his fellow countryman, Johann Caspar Scheuchzer (1702-1729). The young students were particularly impressed by the fact that the elderly scholar, then in his late sixties, possessed a fortune of $£ 300,000$. Sir Hans showed them his wonderful collection which was itself worth $£ 50,000$. In describing it, Haller is all superlatives. The surgeon James Douglas (1675-1742) of Covent Garden showed him many interesting anatomical preparations and drawings compared with which those of William Cheselden (1688-1752), 'a stout young man', were noticeably inferior. (See E. Hintzsche's edition of the diaries, Berne 1968.)

How critical Haller was and with what acuity he appraised the items in the collections. It is understandable that such a wide-ranging intellect as his could not content itself with the small world of Berne, politically important though it be. Nor did the majestic alps, whose praises he so eloquently sung, console him for the lack of scientific opportunities which his native country offered. So it was that in 1736 


\section{Heinrich Buess}

Haller accepted a Chair at the newly-founded University of Göttingen where, among other works, he compiled the first textbook of physiology based on anatomy. Moreover, he commissioned specially-trained artists to prepare magnificent tables based on his dissection of some 350 cadavers with special emphasis on the vascular system. Excellently equipped by his morphological studies, he devoted himself more and more after 1745 to experimental research which, after 1753, he continued in Switzerland. Haller died at the age of sixty-nine years in his native city.

This short biographical sketch was necessary to show you the background to Haller's work on the theory of the movement of the blood. Incidentally, he was known even to his contemporaries as 'the great Haller'. It is now almost twenty years since I first embarked upon a study of the eight enormous volumes which he published under the title Elementa physiologia in Lausanne. Haller worked on this handbook from 1751 to 1765 . He regarded it as his true life's work. It constitutes for us the foundation of a new science. All physiological research up to well into the nineteenth century is based upon Haller. The first two volumes (1757-1760) deal with the anatomy and function of the heart and vessels, some sixty pages being devoted to a defence of William Harvey's doctrine.

Two treatises on the movement of the blood which Haller submitted to the Commentaria of Göttingen Academy of Sciences between October 1754 and March 1756 are far less well known and have so far scarcely been acknowledged. They constitute a preliminary study for the handbook. The first part comprises the text, the second the reports of his experiments. Haller's young friend S. A. A. Tissot (1728-1797) in Lausanne translated the excellent monograph into French. An English translation dating from $\mathbf{1 7 5 7}$ is in the possession of the Library of the Royal College of Physicians of London.

It is impossible to review here even the most important results reported in this special work or indeed in the relevant chapter of the handbook. It will have to suffice here to give a brief outline of his method and the important points from the chapter on the arteries. Peter Wobmann (1967) rightly gives pride of place to Haller's convincing doctrine of open-minded research in his chapter on 'Haller's haemodynamic doctrines'. Haller writes: 'It is necessary to go to work without prejudice, not with the aim of finding out what a classical author has described, but with the desire to discover what nature has created ... I merely present the facts, which as proofs are far superior to theories ... . one must dissect animals but it would be of little use to dissect dead animals; one must take living animals . . . in which one can observe all the movements'. (El. I, III). The cardinal rule must be frequent repetition, i.e. the reproducibility of the experiment. (1.c., S.V.).

What experimental methods and aids did Haller employ? In the introduction of his Elementa he mentions the microscope, injection, desiccation. For the vascular system he also employed puncture and ligation, techniques used already by Galen. Haller, following Harvey's example, preferred to use cold-blooded animals. Moreover, clinical and pathological anatomical observations are particularly valuable for the study of the movements of the blood. Here it may be of interest to note that Haller was the first to produce a thrombosis experimentally, namely in the mesenterial vein of the frog (Buess 1954f). That was in September 1751. His description of the process, 




Figure 1

Daniel Bernoulli (1700-1728). Painting in the Aula of the Museum für Natur- und Völkerkunde, Basle. 

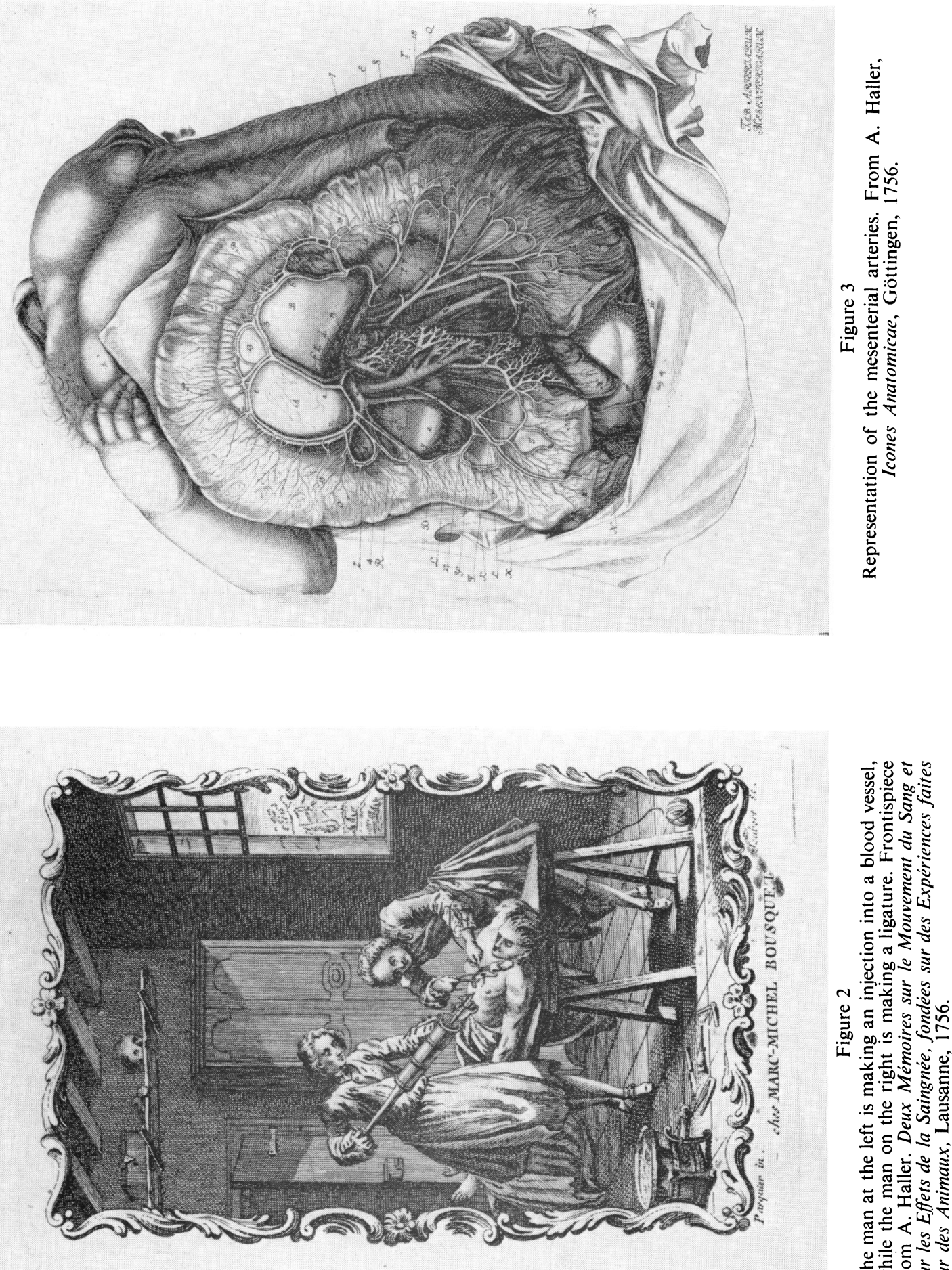


\section{W. Harvey and the Foundation of Modern Haemodynamics by A. von Haller}

which he followed with the microscope, is couched in almost identical terms as in a passage likewise written in French from a paper published in 1881 (by F. W. Zahn, who at that time was an assistant physician at the Pathological Institute in Berne).

Let us now, in conclusion, turn our attention to the arteries, for these are discussed in a particularly important chapter. While recognizing and highly praising the work of Stephen Hales-Haller calls him 'collega noster'-he was not in favour of physical calculation of the kind made by Hales, despite the fact that he had studied mathematics under Johannes Bernoulli (1667-1748) in Basle. Haller's view of the arteries was that they consisted of 'rows of cylinders, joined together in a particular manner' (Buess, 1954). The total hollow space of the branches corresponds 'wholly and entirely to that of the main arterial trunk ..., this applying both to arteries and to veins .... The system of branching with the mutual internal relationships, the angles of bifurcation of the branches, the curvatures and, in particular, the anastomoses are studied first as a whole and then section by section; in these chapters of Elementa the anatomical and physiological discussions are closely inter-related' (ibid.) and united into a new, fundamental doctrine of haemodynamics.

The emphasis in his study of the pulse is a 'first law', as Haller called it in his first treatise. I quote from Wobmann (page 112): 'The pulse arises as a result of the fact that a pulse-wave which had been slowed by various factors is overtaken by a following pulse-wave'. The various factors include, for example, the distance from the heart, i.e. the lessened impulse, and the friction between the blood corpuscles and the vascular wall. Haller analysed the rate of propagation of the pulse-wave and the various types of pulse under special conditions. According to Wobmann, Haller arrived at a doctrine of the pulse 'which is still valid to this day'. Following up observations of Marcello Malpighi (1628-1694) he described the laminar flow of the 'blood cells', i.e. the erythrocytes.

Haller reaches the crowning point of his conclusions in the analysis of 'resistentia', i.e. the external and internal friction in the arteries. The internal friction corresponds to our present-day concept of viscosity. Wobmann has formulated Haller's conclusions as a mathematical relation. A comparison of values calculated with the aid of this formula and present-day values shows, according to this author, that Haller 'had arrived at basically the correct results'. Having regard to the lumen of the vessels, to which Haller did not devote a special chapter, a study of those passages concerning the warm-blooded animals shows that Haller was convinced of the ability of the arteries to contract-this was disputed by Rothschuh.

Summing up then, we may say that from the few examples which have been cited here, Haller's two great achievements are clearly on record. He 'not only confirmed the older and more recent results of previous investigators in a comprehensive manner', but also 'added his own important findings' (Wobmann), derived from his anatomical and experimental investigations. The present 'doctrine of the movements of the blood' goes back, according to Wobmann, 'in most of its aspects' to Haller who 'raised it to the status of a haemodynamic system'. Thus we are fully justified in regarding the Bernese physician as the founder of modern haemodynamics.

The discerning English physiologist, Michael Foster (1836-1907), says in his brilliant Lectures on the History of Physiology (Cambridge 1901) of the Elementa physiologiae: 


\section{Heinrich Buess}

'The year 1757 may be regarded in a certain sense as a red letter year in the history of physiology, as marking an epoch, as indicating the dividing line between modern physiology and all that went before'.

Haller raised his edifice on the pillars provided by the work of William Harvey. And these tributes to Harvey were written by a contemporary physician and poet of the seventeenth century, John Collop (c. 1625 to after 1676). His words include:

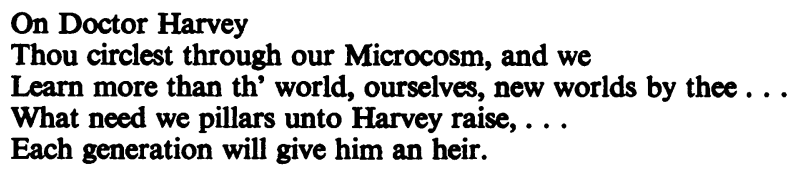

With these beautiful verses by Collop this excursion into the history of physiology has gone full circle.

\section{BIBLIOGRAPHY}

Bernoull, Daniel, Hydrodynamica sive de viribus et motibus fluidorum commentarii, Strassburg, 1738.

BRUNN, WALTER L. von, Kreislauffunktion in William Harvey's Schriften, Berlin, Heidelberg, New York, 1967.

Buess, HeINRICH, 'Notizen zur Geschichte der Sphygmographie', Experimentia, 1947, vol. III, 4, pp. $165-66$, pp. $250-58$.

Buess, HeInRICH, 'Zur Entwicklung der Thromboselehre im 18. Jahrhundert', Schweiz. med. Wschr., 1954, 84, 776-79.

Buess, HeInRICH, 'Marksteine in der Entwicklung der Lehre von der Thombose und Embolie', Gesnerus, 1955, 12, 157-89.

Buess, HeINRICH, 'Zum 300. Todestag von William Harvey (1578-1657)', Dtsch. med. Wschr., 1957, 82, Nr. 29, $1196 \mathrm{ff}$.

Buess, HeInRICH, 'William Harvey (1578-1657) und die praktische Medizin', Praxis, 1958, No. 1, 1-5.

HaRvey, Winliam, The Circulation of the Blood, trans. by Kenneth J. Franklin, Oxford, 1958.

HINTZSCHE, ERICH, 'Albrecht Haller, Tagebuch der Studienreise nach London, Paris, Strassburg und Basle 1727-1728', Berner Beiträge zur Geschichte der Medizin und der Naturwissenschaften, Nr. 1., Berne, 1942, 2nd ed., Berner Beiträge zur Geschichte der Medizin und der Naturwissenschaften, N.S. 2. Berne and Stuttgart, 1968.

HuBER, Fritz, 'Daniel Bernoulli (1700-1782) als Physiologe und Statistiker', Basler Veröffentlichungen zur Geschichte der Medizin und der Biologie, Fasc. VIII, Basle, 1959.

Keele, Kenneth D., William Harvey. The Man, the Physician and the Scientist, Edinburgh and London, E. \& S. Livingstone, 1965.

Keynes, Geoffrey, The Life of William Harvey, Oxford, 1966.

PAGel, WALTER, 'William Harvey: some neglected aspects of medical history', J. Warburg and Courtauld Inst., 1944, 7, 144-53.

PAGel, Walter, William Harvey's Biological Ideas, Basle and New York, 1967.

RothsChUH, KARL E., Entwicklungsgeschichte physiologischer Probleme in Tabellenform, Munich and Berlin, 1952.

SpIESS, OtTo, and VerzÁr, Fritz, 'Eine akademische Festrede von Daniel Bernoulli "Ueber das Leben" (De Vita) gehalten zur Doktorpromotion zweier Kandidaten der Medizin am 4. Oktober 1737', Zwei Beiträge zur Geschichte der Naturwissenschaft, Basle, 1941.

Wobmann, Peter, 'Albrecht von Haller, der Begründer der modernen Hämodynamik', Archiv für Kreislaufforschung, 1967, 52, 96-128. 